\title{
Organic carbon stocks in rubber (Hevea brasiliensis) growing soils of Sri Lanka and strategies to increase: A Review
}

\author{
R S Dharmakeerthi \\ Rubber Research Institute of Sri Lanka, Dartonfield, Agalawatta, Sri Lanka
}

Received: 13 September 2013

\begin{abstract}
Soil plays a pivotal role in global carbon stocks and climate change due to green house gasses. Atmospheric $\mathrm{CO}_{2}$ could be sequestered in soils by converting degraded lands into rubber plantations and by adopting better agro-management practices in existing rubber plantations. This study reviews the information available on soil organic carbon (SOC) stocks in rubber growing soils of Sri Lanka and strategies to increase carbon sequestration in rubber plantations. To date, data generated under the SRICANSOL project were the only available information to estimate SOC stocks down to $1 \mathrm{~m}$ depth in rubber growing areas in Sri Lanka. Calculations made using that data set revealed that the mean SOC stocks in rubber growing soils of Wet, Intermediate and Dry Zone were 105, 85 and $78 \mathrm{Mg} \mathrm{ha}^{-1}$, respectively. In mature rubber plantations, SOC stocks had ranged from 40 to $133 \mathrm{Mg} \mathrm{ha}^{-1}$ and this as a proportion of ecosystem $C$ stock could be varied from 25 to $65 \%$ depending on the soil depth, type, and agro-management practices. Establishment of rubber based agro-forestry systems using perennial crops that incorporate large quantities of organic matter into soil (e.g. cocoa, banana) is the best land use option to sequester atmospheric $\mathrm{CO}_{2}$ in rubber growing soils. Erosion control by establishing a good Mucuna bracteata ground cover since land preparation, establishment of deep rooted vetivar grass or gliricidia as hedgerows and mulching with their loppings, return part of the fuelwood back into rubber field as biochar, adopting favourable agricultural practices that increase growth of the rubber plants were among the key strategies to increase SOC stocks in rubber plantations. The information generated here could be useful when drafting a project design document when tapping into carbon markets.
\end{abstract}

Keywords: Agro-Ecological Regions, carbon sequestration, Hevea, rubber growing soils, soil series, soil organic carbon stock, Sri Lanka

Introduction

World soils represent the largest terrestrial pool of organic carbon, about
$1530 \mathrm{Pg}$ compared with about $760 \mathrm{Pg}$ in atmosphere and $560 \mathrm{Pg}$ in land biota (Lal, 2004). As they can act as a sink for 
and a source of atmospheric $\mathrm{CO}_{2}$, soils play a key role in the global carbon budget and greenhouse effect (Jha et al., 2003). Although an exact magnitude of fluxes from soil to the atmosphere and from biota or land plants to soil are not known, it is apparent that atmospheric carbon pool has increased at the expense of soil pool since clearing of lands for agriculture (Lal \& Kimble, 1997).

After clearing forests for cultivation of crops, soil organic carbon (SOC) levels decrease rapidly and reach a new dynamic equilibrium. SOC level in this new equilibrium is dependent on the management system adopted. Conversion of a natural forest into a rubber plantation has decreased SOC level by $15.6 \%$ in the top soil and by $10.3 \%$ in the sub soil after 60 years of rubber cultivation in India (Karthikakuttiamma et al., 1998). In another study in Malaysia however, top soil SOC levels had decreased from $1.63 \%$ to $1.25 \%$ initially but passed the original level within five years $(1.83 \%)$ under good agro-management practices (Sivanandyan \& Moris, 1992).

Under the current modalities of carbon markets, rubber plantations cannot be recompensed for existing carbon stocks under the clean development mechanism (CDM) payment scheme of the United Nations Framework Convention on Climatic Changes (UNFCCC). It can only create a benefit where rubber plantations are expanding into previously degraded areas, extending their tenure or demonstrating reduced or avoided deforestation and degradation (Jackson, 2013). However, if a land management system can demonstrate that additional $\mathrm{C}$ is sequestered in soil, then there is the possibility to claim $\mathrm{C}$ credits under reducing emissions from deforestation and forest degradation (REDD+) mechanism of the UNFCCC (Lovera, 2012). In order to prove additionality and to claim $\mathrm{C}$ credits, baseline information on SOC stocks prior to the introduction of the management system is a prerequisite.

There was only limited information available under Sri Lankan conditions. While no information available in rubber growing soils, SOC stocks in coconut plantations of two Agroecological Regions and two land suitability classes had ranged from 14.2 to $44.2 \mathrm{Mg} \mathrm{ha}^{-1}$ in the top $30 \mathrm{~cm}$ of soil (Ranasinghe \& Thimothius, 2012). However, SOC stocks could easily be calculated from OC content, bulk density and depth data. A comprehensive data set with all information required to estimate total SOC stocks down to $1 \mathrm{~m}$ depth was available from the SRICANSOL project, a twinning project by the Soil Science Society of Sri Lanka and Canadian Soil Science Society initiated in 1995 and completed in 2009 in 3 phases (Senarath, Dassanayake \& Mapa, 1997; Dassanayake, de Silva \& Mapa, 2003; Dassanayake et al., 2005). Under this project soils of Sri Lanka were classified into series level (series being named as a soil developed from similar parent material with same sequence of genetic horizons in soil 
profile) after characterizing properties in different horizons in soil profiles.

The objective of this study was to estimate SOC stocks in different rubber growing soil series in the Wet Zone (WZ) of Sri Lanka. Since the rubber cultivation in Sri Lanka is expanding into and Intermediate (IZ) and Dry Zone (DZ) areas (Dharmakeerthi et al. 2005; Dharmakeerthi, Chandrasiri \& Edirimanne, 2008; Rodrigo, Iqbal \& Dharmakeerthi, 2011), we compared the SOC stocks in the traditional rubber growing areas with those in some selected soil series in these dryer areas. Later, technologies available to increase SOC stocks when a land is converted to a rubber plantation or in existing rubber lands were reviewed.

\section{Selected soils}

According to Dissanayake, Wijewardena \& Samarappuli (1999) and Samarappuli (2005), there are 17 rubber growing soil series in WZ and IZ of Sri Lanka, 12 of them are in the WZ and 5 in the IZ. Since bulk density data were not available for three soil series (i.e. Boralu, Ukuwela and Weddagala) they were excluded.

Rubber is currently being cultivated in the Ampara district and expanding into Mulativu, Vavuniya and Kilinochchi Districts in the Dry Zone of Sri Lanka. They are mainly confined to crest and upperslope positions in the undulating landscapes in those districts. Therefore, five predominant soil series in such landscapes were also selected (Medawachchiya, Thadaratu, Aluth- wewa, Siyambalanduwa and Aranthalawa) and SOC stocks were calculated to compare with those in the other rubber growing areas. Relative distribution of the benchmark sites of the selected 22 soil series is shown in Fig. 1 .

\section{Estimation of SOC stocks}

From the fact sheets published for benchmark soil series under Phases I, II, and III of the SRICANSOL project (Senarath et al., 1997; Dassanayake et al., 2003; 2005), organic C content, bulk density and horizon thickness data were extracted and SOC stocks were calculated as follows;

$$
\mathrm{SOC}_{\mathrm{T}}=\Sigma\left(\mathrm{BD}_{\mathrm{i}} \cdot \mathrm{d}_{\mathrm{i}} \cdot \mathrm{OC}_{\mathrm{i}}\right)
$$

where, $\mathrm{SOC}_{\mathrm{T}}$ is total SOC stock in 1 ha $\left(\mathrm{Mg} \mathrm{ha}^{-1}\right), \mathrm{BD}_{\mathrm{i}}$ is bulk density in the $\mathrm{i}^{\text {th }}$ horizon $\left(\mathrm{Mg} \mathrm{m}^{-3}\right), \mathrm{d}_{\mathrm{i}}$ is thickness of the $\mathrm{i}^{\text {th }}$ horizon in the solum $(\mathrm{cm})$ and $\mathrm{OC}_{\mathrm{i}}$ is organic $\mathrm{C}$ content in the $\mathrm{i}^{\text {th }}$ horizon $(\%)$. Organic $\mathrm{C}$ content had been measured using the Walkley-Black wet digestion method (Nelson \& Sommers, 1996). The lower boundary of most soil profiles were not clearly defined in the data set. Therefore, horizon data in the entire solum $(\mathrm{A}, \mathrm{AB}, \mathrm{B}$ and $\mathrm{BC}$ horizons) or down to $100 \mathrm{~cm}$ depth, whichever the lowest, were used to calculate the total SOC stock in the soil series. When the horizon thickness was variable an average between the maximum and minimum thickness was used. 


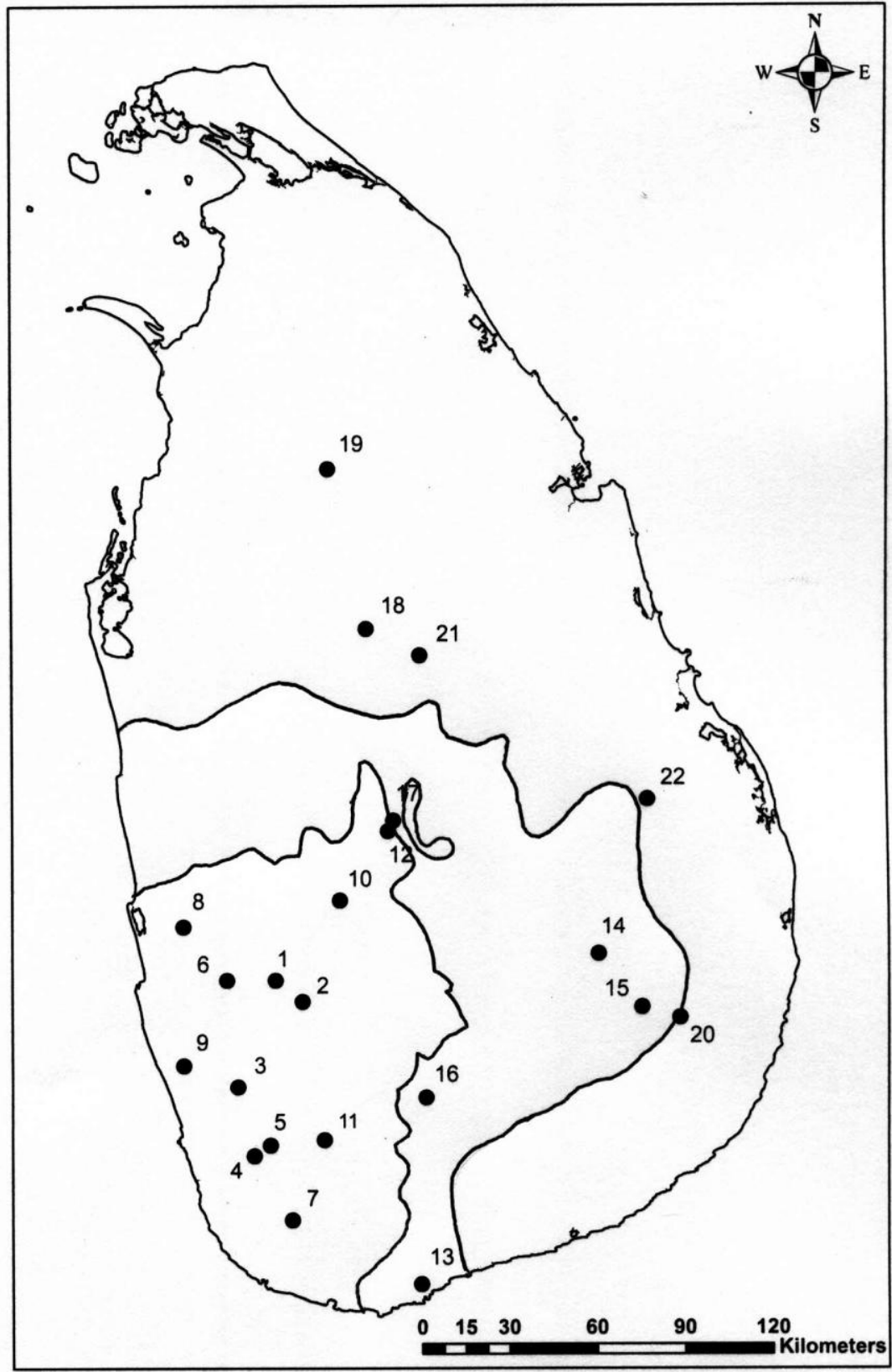

Fig. 1. A map showing the distribution of the benchmark sites of the selected soil series relative to the major Agro-Ecological Regions (WZ, IZ and DZ) of Sri Lanka 
Organic carbon stocks in rubber growing soils

Table 1. Benchmark soil series selected for the study from different Agro-Ecological Regions, their existing vegetation and some important profile characteristics

\begin{tabular}{|c|c|c|c|c|c|c|}
\hline \multirow[b]{2}{*}{ Soil series } & \multirow[b]{2}{*}{$\mathbf{A} \mathbf{E} \mathbf{R}^{\dagger}$} & \multirow[b]{2}{*}{ Vegetation/Land use } & \multirow[b]{2}{*}{$\begin{array}{l}\text { Solum } \\
\text { depth }\end{array}$} & \multicolumn{3}{|c|}{ A horizon } \\
\hline & & & & $\begin{array}{l}\text { Depth } \\
\text { (cm) }\end{array}$ & $\begin{array}{l}\text { OC } \\
(\%)\end{array}$ & $\begin{array}{l}\text { BD } \\
\left(\mathrm{Mg} \mathrm{m}^{-3}\right)\end{array}$ \\
\hline Pallegoda & WL1 & Rubber (uprooted) & $180+$ & 14 & 1.90 & 1.4 \\
\hline Homagama & WL1 & $\begin{array}{l}\text { Rubber ( } 1 \text { year old }) \\
\text { with Pueraria cover }\end{array}$ & $80 / 150$ & 35 & 1.82 & 1.3 \\
\hline Agalawatta & WL1 & $\begin{array}{l}\text { Rubber (mature) with } \\
\text { grass cover }\end{array}$ & $195+$ & 20 & 1.35 & 1.3 \\
\hline Dodangoda & WL1 & $\begin{array}{l}\text { Rubber (mature) with } \\
\text { grass cover }\end{array}$ & $220+$ & 15 & 1.16 & 1.3 \\
\hline Malaboda & WL1 & Tea (VP) & 185 & 23 & 2.86 & 1.3 \\
\hline Pugoga & WL1 & Rubber (mature) & $135+$ & 20 & 1.30 & 1.1 \\
\hline Galigamuwa & WL1 & $\begin{array}{l}\text { Smallholder rubber } \\
\text { (30 year old) }\end{array}$ & $120 / 145+$ & $12 / 15$ & 2.26 & 1.2 \\
\hline Minuwangoda & WL3 & $\begin{array}{l}\text { Smallholder rubber } \\
\text { ( } 5 \text { year old) }\end{array}$ & $65 / 120+$ & 19 & 1.37 & 1.4 \\
\hline Boralu & WL4 & $\begin{array}{l}\text { Rubber (mature) with } \\
\text { grass cover }\end{array}$ & $188+$ & 5 & 1.57 & $\mathrm{NA}^{*}$ \\
\hline Mawanella & WM1 & Rubber (mature) & $44 / 72$ & $14 / 15$ & 1.15 & 1.2 \\
\hline Weddagala & WM1 & NA & $140 / 150+$ & $11 / 18$ & 5.10 & NA \\
\hline Ukuwela & WM3 & Bare, new homestead & $190+$ & $20 / 25$ & 1.00 & NA \\
\hline Beliatta & IL1 & $\begin{array}{l}\text { Home garden, } \\
\text { coconut }\end{array}$ & $50 / 65$ & 27 & 1.80 & 1.4 \\
\hline Bibile & IL2 & Home garden, spice & $75 / 80$ & 30 & 1.60 & 1.4 \\
\hline Dombagahawela & $\begin{array}{l}\text { I(L1- } \\
\text { L2) }\end{array}$ & $\begin{array}{l}\text { Home garden, } \\
\text { sugarcane }\end{array}$ & $180+$ & 28 & 1.00 & 1.4 \\
\hline Mahawalatenna & IM2 & Tea (abandoned) & 180 & $10 / 24$ & 1.20 & 1.7 \\
\hline Matale & IM3 & Rubber forest & $200+$ & 25 & 1.60 & 1.0 \\
\hline Aluthwewa & DL1b & $\begin{array}{l}\text { Homestead (banana, } \\
\text { grass, vegetables) }\end{array}$ & $140+$ & 25 & 1.05 & 1.4 \\
\hline Tadaratu & DL1b & $\begin{array}{l}\text { Upland annuals, } \\
\text { homestead }\end{array}$ & 98 & 28 & 1.26 & 1.6 \\
\hline Siyambalanduwa & DL1b & $\begin{array}{l}\text { Homestead, Upland } \\
\text { annuals }\end{array}$ & 115 & 15 & 0.87 & 1.4 \\
\hline Medawachchiya & DL1b & Teak/shrub jungle & $155+$ & 35 & 0.77 & 1.4 \\
\hline Aranthalawa & DL2 & $\begin{array}{l}\text { Upland annuals, } \\
\text { Homestead }\end{array}$ & 65 & 17 & 0.85 & 1.4 \\
\hline
\end{tabular}

${ }^{\dagger}$ AER - Agro Ecological Region

NA - data not available (Adapted from Senarath et al., 1997; Dassanayake et al., 2003; 2005) 


\section{Some basic properties of selected soils}

Out of the 14 soil series studied in the WZ and IZ, there were rubber in 10 benchmark sites and rubber fields ranged from an uprooted rubber field, 1 to 5 year old immature rubber fields, mature rubber fields to an abundant rubber field (Table 1). The depth of the soil ranged from $44 \mathrm{~cm}$ in the Mawanella series to $220+\mathrm{cm}$ in the Dodangoda series. The depth of A horizon ranged from $5 \mathrm{~cm}$ in the Boralu series soils to $35 \mathrm{~cm}$ in the Homagama series soils. Organic C content was lowest in the Medawachchiya series $(0.77 \%)$ while it was highest in the Weddagala series soils $(5.10 \%)$. The bulk density ranged from 1.1 to $1.7 \mathrm{Mg}$ $\mathrm{m}^{-3}$.

\section{SOC Stocks in Bench Mark soil series} The total SOC stock down to $1 \mathrm{~m}$ depth ranged from 66 to $116 \mathrm{Mg} \mathrm{ha}^{-1}$ in the IZ whereas it ranged from 40 to $133 \mathrm{Mg}$ $\mathrm{ha}^{-1}$ in the WZ (Table 2). The lowest SOC stock was in the Mawanella series and the highest was in the Pallegoda series. The SOC stock in the top $10 \mathrm{~cm}$ ranged from 14 (Mawanella series) to $37 \mathrm{Mg} \mathrm{ha}^{-1}$ (Malaboda series). However, it should be noted that Weddagala series has a very high OC content $(5.6 \%)$ in the A horizon. Since bulk density data were not available for this series, SOC stocks could not be calculated.

Mean SOC stock in the top $1 \mathrm{~m}$ was slightly higher in the WZ soils $(105 \mathrm{Mg}$ $\mathrm{C} \mathrm{ha}^{-1} ; \mathrm{n}=9$ ) than that in the IZ soils ( 85 $\mathrm{Mg} \mathrm{C} \mathrm{ha}^{-1}$; n=5) (Fig. 2). Soil OC in the surface layer is the most sensitive to agro management practices (Schroth et al., 2002). The mean SOC stocks in the top $10 \mathrm{~cm}$ however, were not significantly different (22 and $20 \mathrm{Mg}$ $\mathrm{ha}^{-1}$ in the WZ and IZ, respectively). SOC stock in the top $10 \mathrm{~cm}$ as a percentage of the total SOC stock in the $100 \mathrm{~cm}$ depth was lowest in Agalawatta series soils $(14 \%)$ while it was highest in the Mawanella series soil $(35 \%)$. Depth of the soil profile is highly variable among the studied soil series and depending on the soil depth, the total SOC stock in some soil series could be much higher than those given in the Table 2. For an example, Dodangoda and Matale soil series have $52 \mathrm{Mg} \mathrm{ha}^{-1}$ more $\mathrm{C}$ in the $100-200 \mathrm{~cm}$ depth (data not shown). Average total SOC stock in the top $100 \mathrm{~cm}$ or $10 \mathrm{~cm}$ was the lowest in the DZ soils (78 and $14 \mathrm{Mg} \mathrm{ha}^{-1}$, respectively) among the three AERs. 
Organic carbon stocks in rubber growing soils

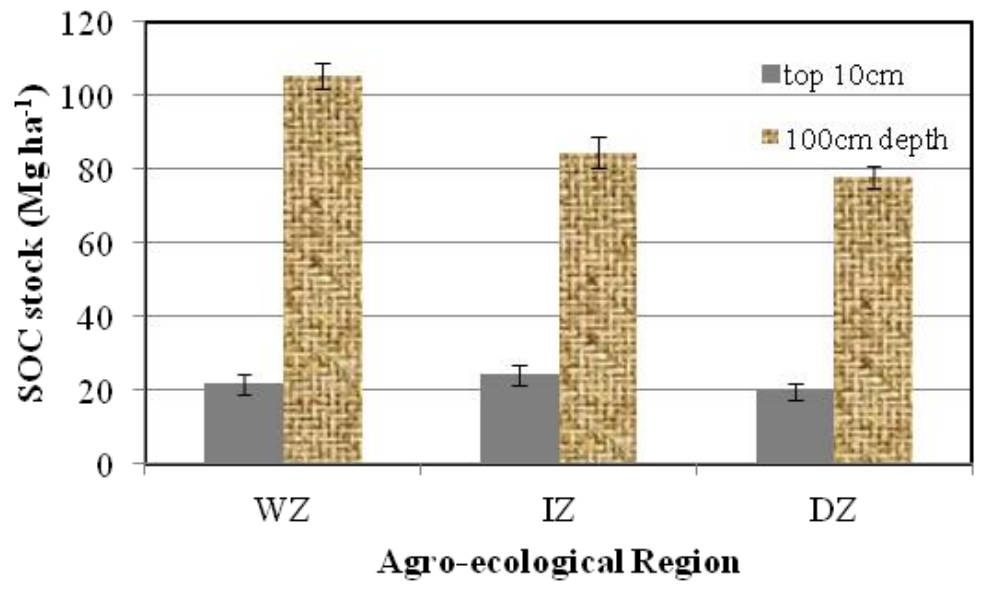

Fig. 2. Estimated mean SOC stocks in the three Agro-ecological regions

Table 2. Soil organic C stocks $\left(\mathrm{Mg} \mathrm{ha}^{-1}\right)$ in top10 $\mathrm{cm}$ layer of the A horizon and total SOC stocks $\left(\mathrm{Mg} \mathrm{ha}^{-1}\right)$ down to a depth of $100 \mathrm{~cm}$ in studied benchmark soils

\begin{tabular}{|c|c|c|c|c|}
\hline AER & Soil series & $\begin{array}{r}\text { Total SOC } \\
\text { stock } \\
\left(\mathrm{Mg} \mathrm{ha}^{-1}\right)\end{array}$ & $\begin{array}{r}\text { SOC stock } \\
\text { in top } \\
10 \mathrm{~cm}\end{array}$ & $\begin{array}{r}\text { SOC in top } \\
10 \mathrm{~cm} \text { as a } \\
\%\end{array}$ \\
\hline \multirow[t]{10}{*}{ Wet Zone } & Pallegoda & 133 & 27 & 20 \\
\hline & Homagama & 133 & 24 & 18 \\
\hline & Agalawatta & 122 & 18 & 14 \\
\hline & Dodangoda & 82 & 15 & 18 \\
\hline & Malaboda & 123 & 37 & 30 \\
\hline & Pugoga & 90 & 14 & 16 \\
\hline & Galigamuwa & 94 & 27 & 29 \\
\hline & Minuwangoda & 131 & 19 & 15 \\
\hline & Mawanella & 40 & 14 & 35 \\
\hline & Mean \pm SD & $105 \pm 35$ & $22 \pm 8$ & $22 \pm 8$ \\
\hline \multirow[t]{6}{*}{ Intermediate Zone } & Beliatta & 68 & 25 & 37 \\
\hline & Bibile & 82 & 22 & 27 \\
\hline & Dombagahawela & 66 & 14 & 21 \\
\hline & Mahawalatenna & 116 & 20 & 18 \\
\hline & Matale & 92 & 16 & 17 \\
\hline & Mean \pm SD & $85 \pm 21$ & $20 \pm 5$ & $24 \pm 8$ \\
\hline \multirow[t]{6}{*}{ Dry Zone } & Aluthwewa & 78 & 15 & 19 \\
\hline & Tadaratu & 99 & 20 & 20 \\
\hline & Siyambalanduwa & 103 & 12 & 11 \\
\hline & Medawachchiya & 74 & 11 & 15 \\
\hline & Aranthalawa & 36 & 12 & 33 \\
\hline & Mean \pm SD & $78 \pm 26$ & $14 \pm 4$ & $20 \pm 8$ \\
\hline
\end{tabular}


Out of the 10 bench mark sites with rubber plantations (Table 1), six (Agalawatta, Dodangoda, Pugoda, Galigamuwa, Mawanella, and Matale) had mature rubber, cultivated intensively as a monocrop, for more than 15 years at the time of sampling. Since SOC content in surface soil of rubber plantations reaches the lowest around 7 (Yang et al., 2004) to 20 (de Blecourt et al., 2013) years after planting, the SOC stocks estimated for the said six soil series could be considered at or near equilibrium state. Other sites except immature rubber were either under a permanent crop or home gardens with upland annual crops for a long period by the time of sampling and therefore could be considered as at equilibrium state. Hence, for estimations of SOC stock due to a change in land use or agromanagement practice, the values given in the Table 2 could be used as the baseline.

\section{Soil groups based on SOC stocks}

Even under a given cropping system, SOC stocks are highly variable across the space depending on the soil type, climate, altitude and specific management practices adopted. As an example, Yang et al. (2005) estimated $202 \mathrm{Mg}$ of SOC ha ${ }^{-1}$ in the top $100 \mathrm{~cm}$ of rubber growing soils in Xishuangbanna prefecture, southwest China while de Blecourt et al. (2013) estimated only $37.4 \mathrm{Mg}$ of SOC $\mathrm{ha}^{-1}$ down to $120 \mathrm{~cm}$ depth in the same region (Table 3). In Indonesia the soil carbon stock was about $90 \mathrm{Mg} \mathrm{ha}^{-1}$ in permanent rubber agroforests and 50 $\mathrm{Mg} \mathrm{ha}{ }^{-1}$ in more intensively managed rotational rubber plantations (Palm et al., 2005; Bruun et al., 2009).

Because of this high variability in SOC stocks, the studied soils were categorized into three groups; high $\left(>100 \mathrm{Mg} \mathrm{ha}^{-1}\right)$, medium (50-100 Mg $\left.\mathrm{ha}^{-1}\right)$ and low $\left(<50 \mathrm{Mg} \mathrm{ha}^{-1}\right)$ SOC stock soils (Table 4). One notable observation was that SOC stocks in soil series in the low category had been limited by the soil depth.

Table 3. Comparison of SOC stocks $\left(\mathrm{MgCh}^{-1}\right)$ in rubber plantations in different countries

\begin{tabular}{llll}
\hline Country & $\begin{array}{l}\text { Depth } \\
(\mathbf{c m})\end{array}$ & $\begin{array}{l}\text { SOC stock } \\
\left(\mathrm{Mg} \mathrm{ha}^{-1}\right)\end{array}$ & Reference \\
\hline Thailand & $0-100$ & $78-178$ & Saengruksawong et al., 2012 \\
Brazil & $0-100$ & 56.3 & Salimo, Wadt \& Alves, 2009 \\
Ghana, & $0-60$ & 135 & Wauters et al., 2008 \\
Brazil & $0-60$ & 153 & Wauters et al., 2008 \\
India & $0-100$ & $45-146$ & Prasannakumari et al., 2005 \\
China & $0-100$ & $111-202$ & Yang et al., 2005 \\
China & $0-120$ & 37.4 & de Blecourt et al., 2013 \\
Sri Lanka & $0-100$ & $40-133$ & This study \\
\hline
\end{tabular}


Organic carbon stocks in rubber growing soils

Table 4. Categorization of rubber growing soils based on the total SOC stocks in the $100 \mathrm{~cm}$ depth

\begin{tabular}{ll}
\hline Category & Soil series \\
\hline Low $\left(<50 \mathrm{Mg} \mathrm{ha}^{-1}\right)$ & Mawanella, Aranthalawa \\
Medium $\left(50-100 \mathrm{Mg} \mathrm{ha}^{-1}\right)$ & Dodangoda, Pugoda, Galigamuwa, Beliatta, Bibile, \\
& $\begin{array}{l}\text { Dombagahawela, Matale, Aluthwewa, Thadaratu, } \\
\text { Medawachchiya } \\
\text { High }\left(>100 \mathrm{Mg} \mathrm{ha}^{-1}\right)\end{array}$ \\
& $\begin{array}{l}\text { Pallegoda, Homagama, Agalawatta, Malaboda, } \\
\text { Minuwangoda, Mahawelatenna, Siyambalanduwa }\end{array}$ \\
\hline
\end{tabular}

Proportion of SOC in ecosystem C

Data on total ecosystem carbon in rubber plantations under Sri Lankan conditions is meager. Allometric estimations of Rodrigo, Munasinghe \& Gunawardena (2005) suggested a 30 year old mature rubber plantation in WZ contains about $67 \mathrm{Mg} \mathrm{C}^{-1}$ in the above ground biomass. Estimates in mature rubber plantations from Brazil, Ghana, Hainan, Indonesia, and Thailand ranged from 60-103 $\mathrm{Mg} \mathrm{ha}^{-1}$ (van Noordwijk, Hairriah \& Sitompul, 2000; Dey, 2005; Cheng, Wang \& Jiang, 2007; Wauters et al., 2008). Generally as much as $10-30 \%$ of above ground biomass $\mathrm{C}$ is stored in the root system (Cheng et al., 2007; Gnanavelrajah et al., 2008; Saengruksawong et al., 2012). If we assume $13 \mathrm{Mg} \mathrm{C}^{-1}$ (about 20\% of above ground biomass) is stored in the root system of intensively managed mature rubber plantation (Dey, 2005), 2 $\mathrm{Mg} \mathrm{C} \mathrm{ha}{ }^{-1}$ is in the litter and ground cover vegetation (de Blecourt et al., 2013), and $133 \mathrm{Mg} \mathrm{ha}^{-1}$ in the SOC to a $1 \mathrm{~m}$ depth (e.g. Pallegoda series soils in the Kalutara region), then the total ecosystem C storage would be $215 \mathrm{Mg}$ $\mathrm{ha}^{-1}$. Therefore, the proportion of SOC in such an ecosystem could be more than $60 \%$. Depending on the soil type and agro-management practices adopted, the proportion of SOC stock in a mature rubber plantation could vary. Under Sri Lankan conditions this could vary from $25 \%$ in a well managed rubber plantation in Mawanella series soils to $65 \%$ in poorly managed rubber plantation in Pallegoda series soil. The maximum proportion could be even higher in soil series where a significant proportion of SOC is stored in deeper layers than $100 \mathrm{~cm}$ such as Pallegoda, Agalawatta and Malaboda.

\section{Dynamics of SOC in a rubber plantation}

It was difficult to find literature to review the effect of land use change into rubber cultivation on SOC stocks. Several studies did not have a clear reference SOC level in the land-use type just prior to rubber plantations, but merely compared the existing land-use types and therefore any detected difference cannot directly be attributed to changes in land use (e.g. Brunn et al., 2009; Yang et al., 2004; Eappen et al., 2005). In general, clearing of land for 
cultivation hasten SOC decomposition and decrease OC input into soil (Zhang et al., 2007a; Rasiah et al., 2004). Zhang et al. (2013) observed that conversion of a seasonal rain forest into rubber plantation in China induced soil and litter decomposition as the quantity and quality of the organic matter inputs under the new land use system are different. The net result is a rapid decline in SOC reserves in the top soil. After this decrease however, soil will reach a new equilibrium with time (de Blecourt et al., 2013). The time at which this new equilibrium is reached and new SOC level is dependent on the agro-management practices adopted. Under best management practices, it is possible to reach the original SOC levels or even higher at short time intervals. Paul et al. (2002) concluded that when agricultural lands are converted into plantations, there was generally an initial decrease in soil organic carbon followed by a gradual increase. In mature rubber plantations, a buildup in SOC stocks after 20 years has been observed by Mandal et al. (2012).

Conversion of forest plantations into rubber plantations could deplete SOC reserves, particularly in hilly landscapes due to erosion of top soil and increased rate of SOC decomposition. In a mountainous landscape in the Yunan Province in China, de Belcourt et al. (2013) observed an exponential decrease in SOC in the top soil with time after converting a secondary forest into a monocrop rubber plantations. The initial rapid decrease in SOC had eventually reached a new equilibrium, after about 20 years and this level was less than initial value. They reported that the decrease in SOC stock was 19\% in $120 \mathrm{~cm}$ depth over a time period of 46 years under rubber cultivation. Karthikakuttyamma et al. (1998) also observed that SOC levels in the top soil decrease after land clearing and never reached the original values under the adopted management practices in some rubber plantations in Kerala. In another study in western Amazonia, Salimon et al. (2009) observed a $41 \%$ decrease in SOC stocks at 17 years after converting a mature forest to a rubber plantation.

Contrary to those observations, Sivanandyan \& Moris (1992) presented data that indicated although SOC levels decreased by $23 \%$ within 9 months after forest clearing, after 62 months (50 months after planting of cover crop and rubber) SOC levels has increased more than $12 \%$ compared to the original levels in the forest. According to them, it is possible to maintain or perhaps even to increase SOC levels if best agricultural practices are adopted after land clearing for rubber cultivation. In another study Krishnakumar et al. (1991) observed a high SOC content in top $60 \mathrm{~cm}$ depth in a 10 to 12 year rubber plantation grown under natural forest conditions compared with a natural forest in an Alfisol in West Bengal. Schroth et al. (2002) also observed that even though the most of changes in SOC is occurring in the top $10 \mathrm{~cm}$ layer, when the entire soil depth 
$(200 \mathrm{~cm})$ is considered, the SOC stocks were similar among natural primary or secondary forests, multi strata tree plantation or mono crop tree plantations in Brazilian Amazonia when fertilizers were applied and a good ground cover was established.

Fox, Castella \& Ziegler (2011) hypothesized that conversion of some short-fallow systems with low carbon stocks to rubber may be carbon positive. In addition, the replacement of truly degraded lands may also prove carbon positive. Review of data from a study that compared 10 to 27 year old rubber plantations with adjacent fields subjected to shifting cultivation in northeast India (Krishnakumar et al., 1990) revealed that SOC stocks in the top $30 \mathrm{~cm}$ of soil in rubber plantations were 17 to $36 \%$ higher. In dry and cold southwest China, Yang et al. (2005) observed about $15 \mathrm{Mg}$ of more $\mathrm{C} \mathrm{ha}^{-1}$ in the top $40 \mathrm{~cm}$ soils in $15-30$ year rubber plantations established on former arable lands when compared with those of nearby arable lands. These findings suggests that, conversion of lands used for shifting cultivation in the Dry Zone of Sri Lanka into permanent rubber based agroforestry systems is likely to increase SOC stocks.

\section{Strategies to increase SOC stocks \\ Erosion control}

Soil erosion is one of the main causes for initial rapid on site decline in SOC stocks. Most of the rubber growing lands have steeply dissected to undulating terrains. Soon after land clearing, disturbed and exposed top soil in such landscapes is subjected to erosive forces of monsoon rains. Joshua (1977) observed that the erosive power of the monsoon rains in Sri Lanka is very high and the erodibility of some red yellow podsolic and immature brown loam soils, predominantly found in rubber growing areas, are also relatively high. In well managed rubber plantations about $90 \%$ of the soil loss due to erosion occurs within the first 2 to 3 years after land clearing and according to Samarappuli \& Yogaratnam (1995) this could be about $60 \mathrm{Mg} \mathrm{ha}^{-1}$. In the study of de Belcourt et al. (2013) reported earlier with a large decline in top soil SOC content, lands on steep slopes had been terraced and the under storey vegetation had been managed by applying weedicide or by slashing which could have resulted a severe erosion of top soil. Unless stringent soil conservation practices are put in place, there could be a huge loss of SOC which will be difficult to replace within reasonable time scales. Number of soil conservation practices such as stone terracing, establishment of drains, silt pits, good cover crop even prior to land clearing, mulching, timing of land preparation, contour planting have been recommended (Sivanandyan \& Moris, 1992; Yogaratnam, 2001). Since erosion is predominant in the first two three years after a land is cleared for rubber cultivation, it is important to establish a good ground cover even prior to land clearing. If soil disturbance could be restricted only to a 
holing operation in places marked for planting, without making platforms along the contour, erosion losses of SOC could be further reduced in hilly landscapes.

For sloping lands susceptible to erosion, agroforestry systems based on contour hedgerow intercropping have been advocated as a means of biological control of erosion, without the high capital costs of mechanical structures (Young, 1989; Lenka et al., 2012). In these systems, hedgerows of trees or shrubs, such as Leucaena spp., Gliricidia sepium or Erythrina spp., or grasses such as vetivar, are planted on the contour in between two rubber rows. Stems and cut branches of hedgerow plants are placed on the ground to slow down run-off, soil particles are deposited and accumulate to create terraces, and water infiltration increases behind the barrier (Craswell et al., 1998). Planting deep rooted vetivar grass as a hedge row is a very effective way of increasing SOC content in subsurface layers (César Izaurralde, Rosenberg \& Lal, 2001; Lavania \& Lavania, 2009). If economically important perennial crops are planted in between rubber rows in rubber based agro-forestry systems, hedge row plants could be established along fences, drains, and in other open spaces. Loppings of these plants could be used periodically as mulching materials.

\section{Ground cover management}

Growing a cover crop not only reduce SOC loss through erosion but also add organic matter into the soil. Litter turn over from leguminous cover crops in immature rubber plantations is estimated to be about 5.5 to $7.5 \mathrm{Mg} \mathrm{ha}^{-1}$ $\mathrm{y}^{-1}$ (Phillip, Geoge \& Punnoose, 2005a). Assuming 36\% C content in the litter from cover crop (Phillip \& Abraham, 2009) this translates to be 1.9 to $2.7 \mathrm{Mg}$ $\mathrm{C} \mathrm{ha}^{-1} \mathrm{y}^{-1}$. Samarappuli et al. (2003) estimated 2.0 and $6.7 \mathrm{Mg}$ of litter $\mathrm{ha}^{-1}$ from Pueraria phasioloides and Mucuna bracteata covers, respectively, in two immature rubber fields of Sri Lanka. Establishment of Mucuna as a cover crop improves SOC content in rubber plantations better than Purarea phasioloids in this aspect (Phillip, Geoge \& Punnoose, 2005b). In a gravelly loam Red Yellow Podsolic soil under Sri Lankan conditions, Samarappuli et al. (2003) observed that OC in the top $30 \mathrm{~cm}$ layer was $1.9 \%$ under Mucuna while that was only $1.0 \%$ under Pueraria, an increase of about 90\% over Pueraria. Such a large increase in SOC content within few years is debatable unless the topmost litter layer had also been included when sampling. In another study in Sri Lanka, Chathurika, Samarappuli \& Mapa (2010) observed, on the average, only $16 \%$ more SOC in the top $30 \mathrm{~cm}$ soil under Mucuna compared to soils under naturals. High biomass production (Samarappuli et al., 2003) and high lignin content in the litter that resist decomposition (Philip \& Abraham, 2009) have lead to high SOC under the Mucuna cover. 


\section{Organic matter application}

It is widely accepted that repeated application of organic residues and manures increases SOC content in the soil. Application of dead mulches around the base of the rubber plants has been proved to increase SOC in top soil (Samarappuli et al., 1998). In traditional rubber growing areas of Sri Lanka, mulching with rice straw has increased OC in the top $10 \mathrm{~cm}$ by $28.5 \%$ compared with Pueraria legume cover (Samarappuli, 1992). However, application of adequate amounts of $\mathrm{N}$, $\mathrm{P}, \mathrm{S}$ and other essential elements is necessary for efficient conversion of crop residues into humus in nutrient deficient soils (Lal, 1998). Application of compost, organic wastes from animal husbandry could also be practiced to increase SOC stocks in soil (Yogaratnum \& Silva, 1987; Affendy et al., 2011).

\section{Introduce agroforestry systems}

Converting monocrop rubber lands into agroforestry systems through intercropping will also improve soil OC contents. Various intercropping systems have been introduced to rubber plantations which include tea, banana, cocoa, pineapple, cinnamon, medicinal plants and annual crops (Rodrigo, 2001). Intercropping with banana during the immature period of rubber has found to significantly increase SOC in top soil (George et al., 2012) and this increase is even greater than maintaining a Puerarea phaseoloides as cover crop. Their data also suggest that intercropping with crops that do not incorporate large quantities of organic matter or residues into soil, such as pineapple and annual crops, will not increase SOC content in rubber growing soils. Zhang et al. (2007b) observed that tea-rubber intercropping tends to sequestrate higher atmospheric carbon in soils than rubber monoculture through increased organic carbon pools in the tea-row soils and reduced organic carbon turnover rates in the rubber-row soils. Calculations done based on data given in Mapa et al. (2008), revealed that intercropping rubber with cocoa in Dombagahawela series in the IZ of Sri Lanka had increased the OC content by $22.3 \%$ and SOC stock by $17.1 \%$ in the top $30 \mathrm{~cm}$ layer compared with monocrop rubber.

In drier areas, inter cropping with sugarcane or corn could be practiced (Esekhade et al., 2003; Idoko et al., 2012; Rodrigo et al., 2000) and these crops also produces large quantities of crop residues. However, return of these residues back to the rubber field is essential to increase SOC stocks, depending on the soil type, as observed in studies carried out in mono crop sugar cane or corn fields in tropical climates (Chivenge et al., 2007; Mann, Tolbert \& Cushman, 2002). Also, adopting conservation tillage practices had lead to SOC accumulation in soils in corn production systems in other countries (Lal, 1998; Paustian, Collins \& Paul, 1997). Although it could be argued that by adopting conservation tillage practices could further increase $\mathrm{C}$ 
sequestration in rubber-sugar cane/corn intercropping systems, the effect of such a system in relation to crop yields under Sri Lankan conditions has to be investigated. Therefore intercropping with perennials appears to be the best option available at present to convert monoculture rubber plantation into an agro-forestry system in order to sequester atmospheric $\mathrm{CO}_{2}$ in rubber growing soils.

\section{Biochar application}

A significant quantity of biomass (fallen twigs and branches) are removed from a rubber land throughout its lifespan as fuelwood by the workers living in and around rubber plantations. In Sri Lanka nearly $50 \%$ of fuelwood requirement in the indrustrial sector is supplied by rubber plantations (Samarappuli et al., 1997). Almost all carbon removed as fuelwood from rubber fields are released to atmosphere as green house gases during gasification. About $50 \%$ of $\mathrm{C}$ in fuelwood can be converted into biochar through pyrolysis (Lehmann, 2007), and energy released during pyrolysis could be used for household cooking using biochar stoves or kilns in raw rubber manufacturing factories (Dharmakeerthi, 2013). Dharmakeerthi and co-workers observed that biochar prepared from rubber wood could be successfully applied to nursery and immature rubber plants as a soil amendment with appropriate fertilizer practices (Dharmakeerthi, Chandrasiri \& Edirimanne, 2012; Dharmakeerthi, 2013). In the dry zone of Sri Lanka corn cobs and sugar cane bagsse could be used for biochar production and return to the field. Since most of the $\mathrm{C}$ in biochar is very stable, soil applied biochar $\mathrm{C}$ will remain in soil for hundreds of years (Liang et al., 2008) increasing OC stocks in soil. Therefore, biochar technology has a great potential to increase SOC stocks in rubber growing soils.

\section{Increase growth of rubber plant}

Photosynthetically sequestered atmospheric $\mathrm{CO}_{2}$ is released to the soil through the root system as organic compounds and root litter (Jobbagy \& Jackson, 2000; Schrumpf, 2013) and leaf fall (Phillip et al., 2003). The higher the rate of photosynthesis, the higher the growth of the plant and $\mathrm{C}$ thus released to the soil will be. Salimon et al. (2009) observed that deep rooted tree species increase SOC contents in lower soil horizons compared with shallow rooted tree species and attributed this increase to the $\mathrm{C}$ released from the root system. Most organic carbon in deep layers are associated with mineral matter and thus protected against decomposition (Schrumpf et al., 2013). Generally $10-35 \%$ of the biomass in a rubber tree is in the below ground (Saengruksawong et al., 2012) of which about $10 \%$ is fine roots (Munasinghe, 2009). Because of the short life span of fine roots, part of that $\mathrm{C}$ is incorporated into SOC pool annually through microbial decomposition. Rubber being a deciduous tree, even greater importance 
could be placed on leaf litter. About 2 to $6 \mathrm{Mg}$ of $\mathrm{C} \mathrm{ha}^{-1}$ could be recycled through the top soil in a mature rubber plantation per year (Phillip et al., 2003; Cheng et al., 2007; de Blecourt et al., 2013). Therefore, management practices that increase growth of both above and below ground biomass will increase the $\mathrm{C}$ content in the soil. Since manipulation of climatic variables that improve crop growth is difficult, management practices that increase soil fertility such as chemical and bio fertilizers, organic manures, and moisture conservation are of great importance in this regard. Application of chemical fertilizers has found to increase SOC in both surface and subsurface layers of a rubber field with a clay loam texture in India (Singh et al., 2010) probably due to high leaf and root litter resulted from the improved growth of the rubber plant, as observed by Singh et al. (1998) for annual crops.

\section{Conclusions}

There were no published data on SOC stocks in rubber growing soils under Sri Lankan conditions. However, a comprehensive data set was available under the SRICANSOL project, a twinning project between the Soil Science Society of Sri Lanka and Canadian Soil Science Society, that could be used to calculate the SOC stock down to $1 \mathrm{~m}$ depth. Calculations made on benchmark soil series in rubber growing areas revealed that the mean SOC stocks of Wet, Intermediate and Dry Zone were 105, 85 and $78 \mathrm{Mg} \mathrm{ha}^{-1}$, respectively. In mature rubber plantations of bench mark sites had recorded SOC stocks ranging from 40 to $133 \mathrm{Mg} \mathrm{ha}^{-1}$ and this as a proportion of ecosystem $\mathrm{C}$ stock could be varied from 25 to $65 \%$ depending on the soil depth and agro-management practices. Rather than cultivating rubber as a monocrop, intercropping with perennials that could add large quantities of organic matter into soils, such as cocoa and banana, is the best land use type in order to sequester atmospheric $\mathrm{CO}_{2}$ in rubber growing soils. Adopting proper soil conservation practices, growing Mucuna as a cover crop, manuring rubber fields, and adding organic matter as mulching materials or biochar could be considered as good agricultural practices to increase $\mathrm{C}$ sequestration in rubber growing soils. Information generated here could be useful when drafting project design documents to claim carbon credits for rubber plantations under the AR-CDM or REDD+ payment schemes of the UNFCCC.

\section{Acknowledgement}

We sincerely thank Professor R.B. Mapa, the team leader of the SRICANSOL project, for providing necessary information and data for this study.

\section{References}

Affendy, H, Aminuddin, M, Azmy, M, Amizi, M A, Assis, $\mathrm{K}$ and Tamer, A T (2011). Effect of organic fertilizers application to the growth of Orthosiphon 
stamineus Benth. intercropped with Hevea brasiliensis Willd. and Durio zibethinus Murr. International Journal of Agricultural Research 6 (2), 180-187.

Bruun, T B, de Neergaard, A, Lawrence, D and Ziegler, A D (2009). Environmental consequences of the demise in swidden cultivation in southeast Asia: carbon storage and soil quality. Human Ecology 37, 375-388.

Chathurika, S, Samarappuli, L and Mapa, R B (2010). Litter accumulation from Mucuna bracteata cover crop and its effects on some soil chemical properties in rubber plantations. Journal of the Rubber Research Institute of Sri Lanka 90, 49-57.

César Izaurralde, R, Rosenberg, N J and Lal, R (2001). Mitigation of climatic change by soil carbon sequestration: issues of science, monitoring, and degraded lands. Advances in Agronomy 70, 1-75.

Cheng, C M, Wang, R S and Jiang, J S (2007). Variation of soil fertility and carbon sequestration by planting Hevea brasiliensis in Hainan Island, China. Journal of Environmental Sciences 19, 348-352.

Chivenge, P P, Murwira, H K, Giller, K E, Mapfumo, P and Six, J (2007). Longterm impact of reduced tillage and residue management on soil carbon stabilization: Implications for conservation agriculture on contrasting soils. Soil \& Tillage Research 94, 328337.

Craswell, E T, Sajjapongse, A, Howlett, D J $B$ and Dowling, A J (1998). Agroforestry in the management of sloping lands in Asia and the Pacific. Agroforestry Systems 38, 121-137.

Dassanayake, A R, de Silva, G G R and Mapa, R B (2003). SRICANSOL
Benchmark Soils of the Intermediate Zone of Sri Lanka: Fact Sheets for Major Soil Series. Soil Science Society of Sri Lanka.

Dassanayake, A R, de Silva, G G R, Mapa, R B and Kumaragamage, D (2005). SRICANSOL Benchmark Soils of the Dry Zone of Sri Lanka: Fact Sheets for Major Soil Series. Soil Science Society of Sri Lanka.

Dey, S K (2005). A preliminary estimation of carbon stock sequestrated through rubber (Hevea brasiliensis) plantation in north eastern region of India. The Indian Forester 131 (11), 1429-1436.

de Blecourt, M, Brumme, R, Xu, J, Corre, M D and Veldkamp, E (2013). Soil carbon stocks decrease following conversion of secondary forests to rubber (Hevea brasiliensis) plantations. PLoS ONE 8(7), e69357. doi:10.1371/ journal. pone.0069357.

Dharmakeerthi, R S (2013). Biochar: Benefits aplenty for rubber planters and workers. Rubber Asia. Jul-Aug 2013 pp. 66-71. http://issuu.com/ dhanam publications/docs/rubber-asia-julyaugust2013/69? $=3386873 / 4174718$.

Dharmakeerthi, R S, Silva, S N, Yakandawala, A and Jayasinghe, W K (2005). Nutritional status of rubber growing soils in the Monaragala district. Journal of the Rubber Research Institute of Sri Lanka 87, 23-35.

Dharmakeerthi, R S, Chandrasiri, J A S and Edirimanne, V (2008). Agroclimatalogical potential of the Hambantota district for rubber cultivation. Bulletin of the Rubber Research Institute of Sri Lanka 49, 1722.

Dharmakeerthi, R S, Chandrasiri, J A and Edirimanne, V U (2012). Effect of rubberwood biochar on nutrition and 
growth of nursery plants of Hevea brasiliensis established in an Ultisol. SpringerPlus 1, 84.

Dissanayake, S T B, Wijewardena, J D H and Samarappuli, L (1999). Management of the Wet Zone soils. In: Soils of the Wet Zone of Sri Lanka. pp.160-175 (Eds. R.B. Mapa, S. Somasiri and S. Nagarajah), Soil Science Society of Sri Lanka.

Eappen, T, Rao, D V K N, Karthikakuttyamma, M, Sarma, A C, Dey, S K, Varghese, Y A and Krishnakumar, A K (2005). Influence of plantation crops on soil properties in Thripura. Natural Rubber Research 18 (1), 67-80.

Esekhade, T U, Orimoloye, J R, Ugwa, I K and Idoko, S O (2003). Potentials of multiple cropping system in young rubber plantations. Journal of Sustainable Agriculture 22(4), 79-94.

Fox, J, Castella, J C and Ziegler, A D (2011). Swidden, Rubber and Carbon: Can REDD+ Work for People and the Environment in Montane Mainland Southeast Asia? CCAFS Working Paper No.9. CGIAR Research Program on Climate Change, Agriculture and Food Security (CCAFS). Copenhagen, Denmark. www.ccafs.cgiar.org.

George, E S, Joseph, P, Jessey, M D, Joseph, K and Nair, N U (2012). Influence of inter cropping on growth of rubber (Hevea brasiliensis) and soil physic-chemical properties. Natural Rubber Research 25 (1). 39-45.

Gnanavelrajah, N, Shrestha, R P, SchmidtVogt, D and Samarakoon, L (2008). Carbon stock assessment and soil carbon management in agricultural landuses in Thailand. Land Degradation and Development 19, 242-256.

Idoko, S O, Ehigiator, J O, Esekhade, T U and Orimoloye, J R (2012). Rubber, maize and cassava intercropping systems on rehabilitated rubber plantation soil in south eastern Nigeria. Journal of Agriculture and Biodiversity Research 1 (6), 97-101.

Jackson, E (2013). Tapping into Carbon Markets and Finance. International Rubber Research and Development Board, Malaysia. 8pp.

Jha, M N, Gupta, M K, Saxena, A and Kumar, R (2003). Soil organic carbon store in different forests in India. The Indian Forester 129 (6), 714-724.

Jobbagy, E G and Jackson, R B (2000). The vertical distribution of soil organic carbon and its relation to climate and vegetation. Ecological Applications 10, 423-436.

Joshua, W D (1977). Soil erosive power of rainfall in the different climatic zones of Sri Lanka. Proceedings of Symposium on Erosion and Solid Matter Transport in Inland Waters. Publ. No. 122. Paris, IAHS-AISH.

Karthikakuttyamma, M, Suresh, P R, Prasannakumari, P, Geroge, V and Aiyer, R S (1998). Effect of continuous cultivation of rubber (Hevea brasiliensis) on morphological features and organic carbon, total nitrogen, phosphorous and potassium contents of soil. Indian Journal of Natural Rubber Research 11 (1\&2), 73-79.

Krishnakumar, A K, Eappen, T, Rao, N, Potty, S N and Sethuraj, M R (1990). Ecological impact of rubber (Hevea brasiliensis) plantations in North east India. 1. Influence on soil physical properties with special reference to moisture retention. Indian Journal of Natural Rubber Research 3 (1), 53-63.

Krishnakumar, A K, Guptha, C, Sinha, R R, Sethuraj, M R, Potty, S N, Eappen, $\mathrm{T}$ and Das, K (1991). Ecological impact 
of rubber (Hevea brasiliensis) plantations in north east India. 2. Soil properties and biomass recycling. Indian Journal of Natural Rubber Research 4 (2), 134-141.

Lal, R (1998). Land use and soil management effects on soil organic matter dynamics on Alfisols in Western Nigeria. In: Soil Processes and the Carbon Cycle. pp109-126. (Eds. R. Lal, J.M. Kimble, R.F. Follett and B.A. Stewart), CRC Press LLC.

Lal, R (2004). Soil carbon sequestration to mitigate climate change. Geoderma $\mathbf{1 2 3}$, $1-22$.

Lal, R and Kimble, J M (1997). Conservation tillage for carbon sequestration. Nutrient Cycling in Agroecosystems 49, 243-253.

Lavania, U C and Lavania, S (2009). Sequestration of atmospheric carbon into subsoil horizons through deep-rooted grasses - vetiver grass model. Current Science 97 (5), 618-619.

Lehmann, J (2007). Bio-energy in the black. Frontiers in Ecology and Environment 5, 381-387.

Lenka, N K, Dass, A, Sudhishri, S and Patnaik, U S (2012). Soil carbon sequestration and erosion control potential of hedgerows and grass filter strips in sloping agricultural lands of eastern India. Agriculture, Ecosystems \& Environment 158, 31-40.

Liang, B, Lehmann, J, Solomon, D, Sohi, S, Thies, J E, Skjemstad, J O, Luizao F J, Engelhard, M H, Neves, E G and Wirick, S (2008). Stability of biomassderived black carbon in soils. Geochimica et Cosmochimica Acta 72, 6069-6078.

Lovera, S (2012). MRV as a Trojan Horse for Carbon Markets? Redd -Monitor.org, pp.1-2. http://www. redd-monitor.org/2012/12/04/guest-postmrv-as-a-trojan- horse-for- carbonmarkets/ [Accessed Aug. 25, 2013].

Mandal, D, Pal, T K, Dey, S K and Jacob, J (2012). Changes in organic carbon and some soil properties under rubber (Hevea brasiliensis) plantation in subtropical Tripura. Natural Rubber Research 25 (1), 13-20.

Mann, L, Tolbert, V and Cushman, J (2002). Potential environmental effects of corn (Zea mays L.) stover removal with emphasis on soil organic matter and erosion. Agriculture Ecosystem and Environment 89, 149-166.

Mapa, R B, Bandara, B M W N, Gunaratne, W D L and Idamekorale, P R (2008). Effect of rubber-cocoa intercropping on soil water retention of an immature brown loam soil (Inceptisols) of Sri Lanka. Sri Lankan Journal of Agricultural Science 45, 88-99.

Munasinghe, E S (2009). Growth, yield, carbon fixation and economics of rubber cultivation in Sri Lanka. PhD Thesis, University of Sri Jayawardenapura, Sri Lanka.

Nelson, D W and Sommers, L E (1996). Total carbon, organic carbon and organic matter. In: Methods of Soil Analysis. Part 3: Chemical methods. pp. 9611010. (Eds. D.L. Sparks, A.L. Page, P.A. Helmke, R.H. Loeppert, P.N. Soluanpour, M.A. Tabatabai, C.T. Johnston, and M.E. Sumner), SSSA Book Series No. 5, SSSA and ASA, Madison, WI, USA.

Palm, C A, van Noordwijk, M, Woomer, P, Alegre, J C, Arévalo, L, Castilla, C E, Cordeiro, D G, Hairiah, K, Kotto-Same, J, Moukam, A, Parton, W J, Ricse, A, Rodrigues, $\mathrm{V}$ and Sitompul, S M (2005). Carbon losses and sequestration after land use changes on the humid 
tropics. In: Slash-and-Burn Agriculture: The Search for Alternatives. pp. 41-63 (Eds. C.A. Palm, S.A. Vosti, P.A. Sanchez and P.J. Ericksen), Columbia University Press, New York.

Paul, K I, Polglase, P J, Nyakuengama, J G and Khanna, P K (2002). Change in soil carbon following afforestation. Forest Ecology and Management 168, 241-257.

Paustian, K, Collins, H P and Paul, E A (1997). Management controls on soil carbon. In: Soil Organic Matter in Temperate Agroecosystems: Long-term experiments in North America. pp 15-49 (Eds. E.A. Paul, K.Paustian, E.A. Elliott and Cole, C.V.), CRC Press, Boca Raton.

Phillip, A and Abraham, J (2009). Litter chemistry and decomposition in rubber plantations. Natural Rubber Research 22 (1\&2), 10-16.

Phillip, A, Phillip, V, Geoge, E S, Punnoose, K I and Mathew, M (2003). Leaf litter decomposition and nutrient release in a fifteen-year-old rubber plantation. Indian Journal of Natural Rubber Research 16 (1\&2), 81-84.

Phillip, A, Geoge, E S and Punnoose, K I (2005a). Comparative evaluation of dry matter production and nutrient accumulation in the shoots of Pueraria phaseoloides Benth and Mucuna bracteata D.C. grown as cover crop in an immature rubber (Hevea brasiliensis) plantation. Natural Rubber Research 18(1), 87-92.

Phillip, A, Geoge, E S and Punnoose, K I (2005b). Effect of Pueraria phaseoloides and Mucuna bracteata on the physicchemical properties of soils of immature rubber plantations. Natural Rubber Research 18 (1), 93-100.

Prasannakumari, P, Rao, D V K N, Elsie, S G and Punnoose, K I (2005). Study of soils in non-conventional areas of rubber cultivation in Kerala and their effect on growth and yield of Hevea brasiliensis. Natural Rubber Research 18 (1), 38-45.

Ranasinghe, C S and Thimothias, K S H (2012). Estimation of carbon sequestration potential in coconut plantations under different agroecological regions and land suitability classes. Journal of the National Science Foundation of Sri Lanka 40 (1), 77-93.

Rasiah, V, Florentine, S K, Williams, B L and Westbrooke, M E (2004). The impact of deforestation and pasture abandonment on soil properties in the wet tropics of Australia. Geoderma 120, 35-45.

Rodrigo, V H L, Nugawela, A, Sivanathan, A, Witharama, W R G, and Jayasinghe, W K (2000). Rubber cum sugarcane intercropping: A suitable cropping system for farmers in the intermediate zone of Sri Lanka. Journal of the Rubber Research Institute of Sri Lanka 83, 62 74.

Rodrigo, V H L (2001). Rubber based intercropping systems. In: Handbook of Rubber, Volume 1: Agronomy. pp.139155. (Eds. L.M.K. Tillekeratne and A. Nugawela), Rubber Research Institute of Sri Lanka, Agalawatta, Sri Lanka.

Rodrigo, V H L, Munasinghe, E S and Gunawardena, U A D P (2005). Development of simple protocol for in situ assessments of timber, biomass and carbon in the rubber crop. Preprints of papers of the International Natural Rubber Conference, Cochin, India (6-8 November 2005). 246-255 pp.

Rodrigo, V H L, Iqbal, S M M and Dharmakeerthi, R S (2011). Potential for rubber (Hevea brasiliensis Muell. Arg.) cultivation in the Eastern Province of Sri Lanka. Journal of the National 
Science Foundation of Sri Lanka 39 (4), 403-411.

Saengruksawong, C, Khamyong, S, Anongrak, N and Pinthong, J (2012). Growths and carbon stocks of para rubber plantations on Phonpisai soil series in Northeastern Thailand. Rubber Thai Journal 1, 1-18.

Salimon, C, Wadt, P G and Alves, S (2009). Decrease in carbon stocks in an oxisol due to land use and cover change in southwestern Amazon. Ambiente e Agua - An Interdisciplinary Journal of Applied Science 4, 57-65.

Samarappuli, L (1992). Some agronomic aspects in overcoming moisture stress in Hevea brasiliensis. Indian Journal of Natural Rubber Research 5, 127-132.

Samarappuli, L (2005). Management of the Intermediate Zone soils: Rubber. In. Soils of the Intermediate Zone of Sri Lanka. pp.199-201 (Eds. R.B. Mapa, A.R. Dissanayake and H.B. Nayakakorale), Soil Science Society of Sri Lanka.

Samarappuli, L and Yogaratnam, N (1995). Rubber plantations as self-sustaining agroforestry systems. Sri Lanka Forester, 22 (3\&4), 1-12.

Samarappuli, I N, Tillekeratne, L M K, Silva, K D and Wickramaratne, C S (1997). Environmental linkages of rubberwood industry. Bulletin of the Rubber Research Institute of Sri Lanka 35, 22-41.

Samarappuli, L, Yogaratnam, N, Karunadasa, $\mathrm{P}$ and Mitrasena, U (1998). Effects of mulching with rice straw on soil chemical properties and its influence on the performance of Hevea. Journal of Rubber Research 1 (4), 263277.

Samarappuli, L, Karunadasa, P, Mitrasena, U and Shantha, N (2003). Mucuna bracteata: Ideal cover crop for efficient soil and water management in rubber cultivation. Journal of Tropical Agricultural Research and Extension 6, 87-90.

Schrumpf, M, Kaiser, K, Guggenberger, G, Persson, T, Kogel-Knabner, I and Schulze, E D (2013). Storage and stability of organic carbon in soils as related to depth, occlusion within aggregates, and attachment to minerals. Biogeoscience 10, 1675-1691.

Schroth, G, D'Angelo, S A, Teixeira, W G, Haag, D and Lieberei, R (2002). Conversion of secondary forest into agroforestry and monoculture plantations in Amazonia: consequences for biomass, litter and soil carbon stocks after 7 years. Forest Ecology and Management 163, 131-150.

Senarath, A, Dassanayake, A R and Mapa, R B (1997). SRICANSOL Benchmark soils of the Wet Zone: Fact sheets for the major soil series. Soil Science Society of Sri Lanka.

Sing, B R, Borresen, T, Uhlen, G and Ekeberg, E (1998). Long-term effects of crop rotation, cultivation practices, and fertilizers on carbon sequestration in soils in Norway. In: Management of Carbon Sequestration in Soil. Pp.195208 (Eds. R. Lal, J.M. Kimble, R.F. Follett and B.A. Stewar), CRC Press LLC.

Singh, R P, Mandal, D, Joseph, M and Sharma, C (2010). Response of rubber (Hevea brasiliensis) to NPK fertilizers in the lower Brahmaputra valley zone of Assam. Natural Rubber Research $\mathbf{2 3}$ (1\&2). 28-36.

Sivanandyan, K and Moris, N (1992). Consequence of transforming tropical rain forests to Hevea plantations. The Planter 68 (800), 547-567. 
van Noordwijk, M, Hairriah, $\mathrm{K}$ and Sitompul, S M (2000). Reducing uncertainties in the assessment at national scale of $\mathrm{C}$ stock impacts of land use change. Proceedings of IGES/NIESWorkshop on GHG Inventories for Asia-Pacific Region, 910, March 2000. DOA: October 18, 2006 from www.gcte.org/ MeetRep(3)-Uncert Cstock-Mains'paper.pdf.

Wauters, J B, Coudert, S, Grallilen, E, Jonard, M and Ponette, Q (2008). Carbon stock in rubber tree plantations in Western Ghana and Mato Grosso (Brazil). Forest Ecology and Management 255, 2347-2361.

Yang, J C, Huang, J H, Pan, Q M, Tang, J W and Han, X G (2004). Long-term impacts of land-use change on dynamics of tropical soil carbon and nitrogen pools. Journal of Environmental Sciences-China 16, 256-261.

Yang, J C, Huang, J H, Tang, J W, Pan, Q $M$ and Han, $X$ G (2005). Carbon sequestration in rubber tree plantations established on former arable lands in Xishuangbanna, SW China. Acta Phytoecologica Sinica 29 (2), 296-303.

Yogaratnam, N (2001). Land suitability evaluation, selection and soil conservation. In: Handbook of Rubber, Volume 1: Agronomy. pp 1-11 (Eds. L.M.K. Tillekeratne and A. Nugawela),
Rubber Research Institute of Sri Lanka. Agalawatta, Sri Lanka.

Yogaratnam, N and Silva, F P W (1987). Use of organic materials as fertilizers. Bulletin of the Rubber Research Institute of Sri Lanka 24, 17-20.

Young, A (1989). Agroforestry for Soil Conservation. CAB International, Wallingford, UK.

Zhang, H, Zhang, G L, Zhao, Y G, Zhao, W J and Qi, Z P (2007a). Chemical degradation of a Ferralsol (Oxisol) under intensive rubber (Hevea brasiliensis) farming in tropical China. Soil Tillage Research 93, 109-116.

Zhang, M, Fu, X F, Feng, W T and Zou, X (2007b). Soil organic carbon in pure rubber and tea-rubber plantations in South-western China. Tropical Ecology 48(2), 201-207.

Zhang M, Schaefer, D A, Chan, O C and Zou, X (2013). Decomposition differences of labile carbon from litter to soil in a tropical rain forest and rubber plantation of Xishuangbanna, Southwest China. European Journal of Soil Biology 55, 55-61.

Address for correspondence: Dr R.S. Dharmarkeerthi, Department of Soil Science, Faculty of Agriculture, University of Peradeniya, Peradeniya 20400, Sri Lanka. e-mail:dharmakeerthirs@gmail.com 